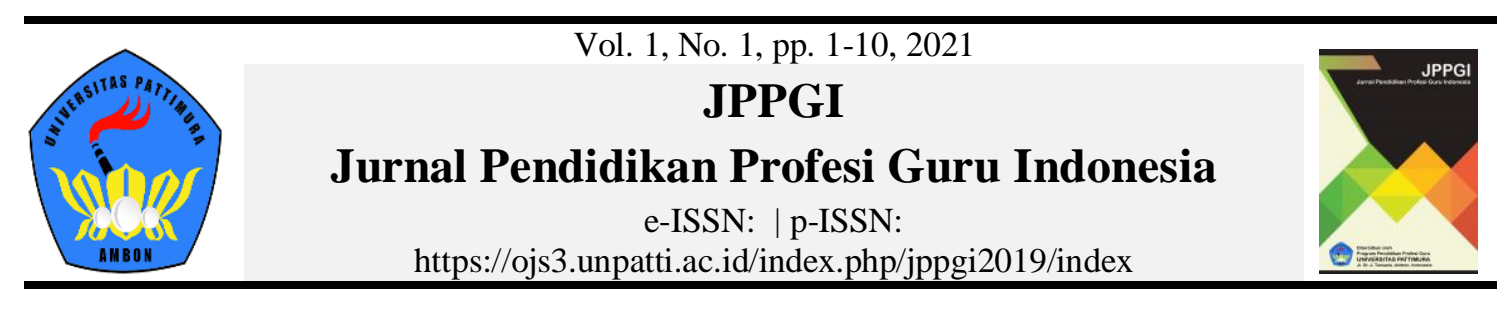

\title{
Metaphorical and Strategic Competence in the Spanish Language Teaching Classroom as a Foreign Language through Task-Based Learning Methodology
}

\author{
Javier Julian Enriquez \\ Department of English Education, Polytechnic University of Valencia, Spain \\ *Corresponding e-mail: jajuen@alumni.upv.es \\ Received: 22 July 2020 \\ Accepted: 05 November 2020 \\ Online Published: 08 February 2021

\begin{abstract}
This article focuses on highlighting the application of discourse analysis in the Spanish Language Teaching as a Foreign Language. Especially, it does emphasize the importance of the conceptual fluency acquisition, as a strategic competence in particular, and as a communicative competence in general for non-native speakers of other languages enrolled in Spanish courses as a foreign language. That is, it does draw attention to Metaphorical Competence (MC), which can be defined as the ability to acquire, create, and interpret metaphors in the target language. For this purpose, we have chosen a Golden Age poet, Gongora, considered by most literary critics as the most influential and important poet in Spanish-language poetry, whose works represent the most admirable literary masterpieces in the western classical literature and Baroque poetry. In the same way, we would like to bring to light his literary value, excellent, and didactic potential for teaching poetry in the second language classroom, underpinned by a Task-based Learning methodology.
\end{abstract}

Keywords: Metaphorical competence (MC), Discourse analysis, Conceptual fluency, Strategic competence, Communicative competence, Gongora, Golden age, Task-based learning

To cite this article:

Enriquez, J. J. (2021). Metaphorical and strategic competence in the spanish language teaching classroom as a foreign language through task-based learning methodology. JPPGI: Jurnal Pendidikan Profesi Guru Indonesia, 1(1), 1-10.

\section{INTRODUCTION}

This article's main objective is to set out the reasons for the application of discourse analysis as a methodology to solve certain problems in the language teaching setting. Particularly, it does aim to cope with the difficulty of teaching literature and poetry in Spanish Language Teaching as a Foreign Language, both in relation to the pragmatics or language in context and to the textual linguistics that deals with the text coherence and structure. To this end, the analysis and study of a literary text constitutes the way to accomplish this goal. Then, we will attempt a recreation of original approaches from existing materials and of actual data from teachers, who have analyzed this tricky issue, that is, how to define the communicative literature function. Hence, we believe that it would be possible to undertake research on youngest students in the 
classroom context to find out and assess why some literary texts, in particular, for example, those referring to poetry are not accepted in the same way as those belonging to any other type of texts. Authors whose works are part of the Golden Age literature, such as Cervantes, Gongora, or Quevedo, so important for the Spanish language are no longer studied. Why not can we find a solution from the Applied Linguistics perspective? It is a widely held belief that defining the communicative literature function has been an arduous and difficult task for many years; in this way, even if it is a complex task, why not try it? However, this is not the case, which concerns us in this paper, but the crux of the matter is whether this sonnet's pragmatic context, insofar as a writing poem, is designed to involve every possible reader as an introduction to any subjects, regardless of the epoch in which he or she lives or could have lived.

\section{METHOD}

\section{Research Design}

To carry out this work, we will adopt the methodology based on the Task-Based Learning according to Staire (2004). Subsequently, as stated by this author, the large number of encompassing proposals under the term 'Task-Based Learning' makes it necessary to specify the steps involved in the classroom-focused development. In this article, we put forward a framework for the designs of task-based teaching units that allow incorporating into practice the principles on which the new approach is based. To this end, firstly, we start with an example of typical didactic units within the "communicative" courses, based on the notion-functional approach, which will allow us to contrast it to a design through tasks and appreciate their differences. Next, we present the general framework of the target teaching unit design, which will allow seeing the steps to follow and the elements that integrate it. Then, we describe the characteristics of each phase of the process. Finally, we explain the levels of the framework application in relation to some different aspects of the work in the foreign language classroom, from its joint use with a textbook at the level of language used in the unit.

\section{Sample}

Like this manner, this literature lesson, underpinned by Task-Based Learning in Second Language Acquisition (SLA) according to Staire's methodology, is largely aimed at the students with an advanced $\mathrm{C} 1$ and $\mathrm{C} 2$ level in accordance with The Common European Framework of Reference for Languages (CEFR).

\section{Research Instrument}

Materials for undertaking tasks: computers, internet connection, dictionaries, card photocopies relating to each of the tasks. In that way, this serves the following purposes:

1. Integrate Information and Communication Technology (ICT) in the learning process, as a key competence and contributing to the acquisition of the target foreign language;

2. Use ICT in the classroom to work on information processing, authentic communication, and on the learner autonomy, as the builder of his or her own learning process;

3. Give ICT a role to help young people be able to arrange, evaluate, and decide on the information that comes to them;

4. Challenge students with different types of supports and formats and, therefore, a great variety of activities in which they pass from receivers to makers; 
5. Bring students to the real contact with the target foreign language and users (whether natives or not), by means of the electronic mail, "chats", "blogs", or spaces wiki;

\section{Procedure}

This lesson plan, which is based on Staire's guide (2004), explains 'how to organize this teaching unit through task-based learning':

1. Choice of topic or area of interest: the poetry by Gongora.

2. Final task: elaborate a final poetic text by the whole class.

3. Specifying communicative goals: during this unit, learners will develop the ability to:

a) Recognize the communicative function and textual competence of this sonnet, compare with each other and adapt them for the poetic text of the final task;

b) Look for the significant lexical choices in this poetic text: rhetorical and pragmatic tropes;

c) Use and recognize the procedures to achieve both the linear and global cohesion and coherence within this poem;

d) Learn linguistic forms: morphological and lexical categories, phrase and utterance structures.

4. Final scheduling demonstrating the achievement of the objectives: Reading by looking or scanning for specific information from the text, speaking by discussing the tasks performed by all the students of each group, etc.

5. Specifying thematic and linguistic components necessary and desirable for the final task: learn vocabulary related to the task on target, turn to literary resources and their pragmatic context of the original poem to elaborate the final poetic text, etc.

6. Planning process: sequencing of steps to go through enabling tasks and communication tasks.

7. Incorporated assessment and evaluation as part of the learning process: these tasks aim to develop the skills of self-monitoring and self-evaluation, as well as the initial, and continuous formative feedback.

8. Allotted time

\section{Data Analysis Techniques}

In order to explore student experience learning in this teaching unit, a thorough evaluation, survey was conducted. That is, a focus group was carried out with students becoming involved in such a task just after the class sessions ended. This focus group, with all twenty-four students participating whose their native languages were Russian, Chinese, and English, was conducted during the third day of class belonging to Active Methodologies and Simulation, Game, and Technology as Teaching and Research, Master in Languages and Technology; specifically, in May 2014, Polytechnic University of Valencia, Spain. Students were informed that this focus group was part of our research project exploring active teaching methods and that we were interested in their feedback on the target-teaching unit. In view of that, the focus group, arranged in six groups of four students, completed the survey through Google Drive underpinned by both quantitative and qualitative data analysis. 


\section{RESULTS AND DISCUSSION}

It follows that the planning, the teaching unit development, a final task, and eventually an evaluation determine the Task-Based Learning approach in the teaching unit itself.

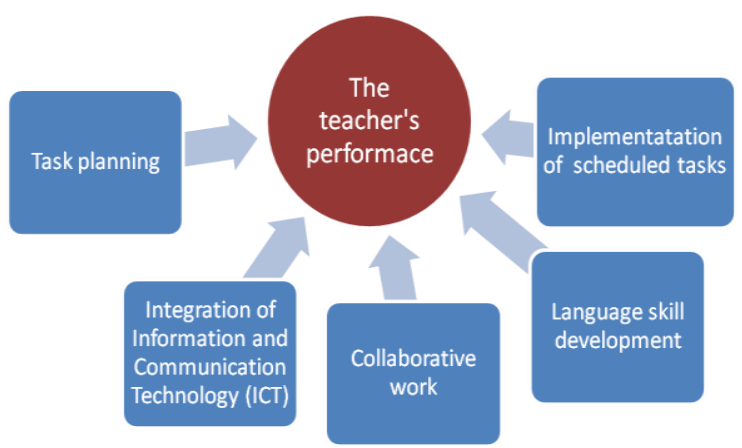

Figure 1. The teacher's performance

As can be seen, it now becomes evident to us that in these activities, the fundamental characteristics of a communication task as indicated by Nunan, Staire, or Aronson does take place. That is, it involves all students in the comprehension, production and interaction during the task process, its attention focuses mainly on meaning rather than on form; it is structured with a beginning, an end and a clear work procedure, an objective, a content and concrete results.

The different aspects we must taken into account to evaluate the activities are reflected in the image that we offer below. We consider it essential to know the students' perception, both in terms of what has been learned and in terms of the suggestions for future actions.

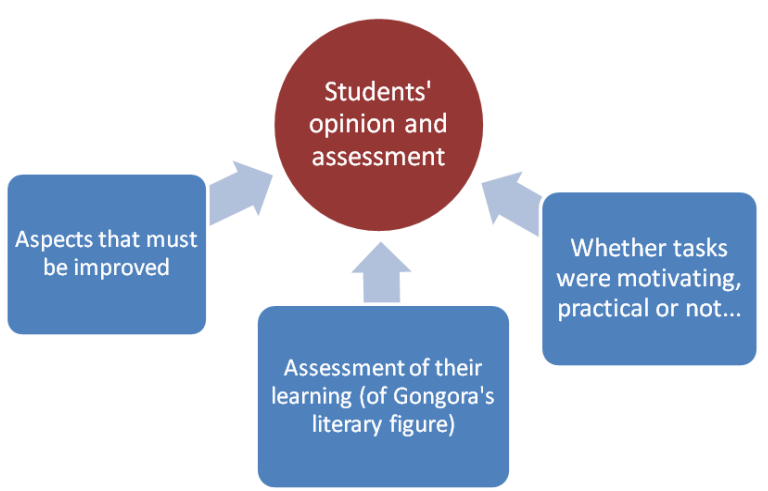

Figure 2. Assessment aspects

Next, we present the data collected from the participating six student groups' answers through Google Drive. Quantitative data:

Did the teaching unit work well?

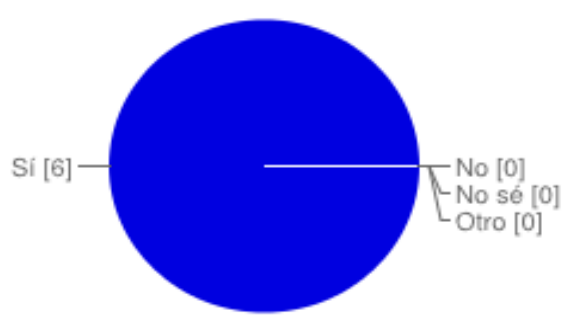




$\begin{array}{lll}\text { Yes } & 24 & 100 \% \\ \text { Non } & 0 & 0 \% \\ \text { I do not } & 0 & 0 \% \\ \text { Another answer } & 0 & 0 \%\end{array}$

What did you like most about the teaching unit?

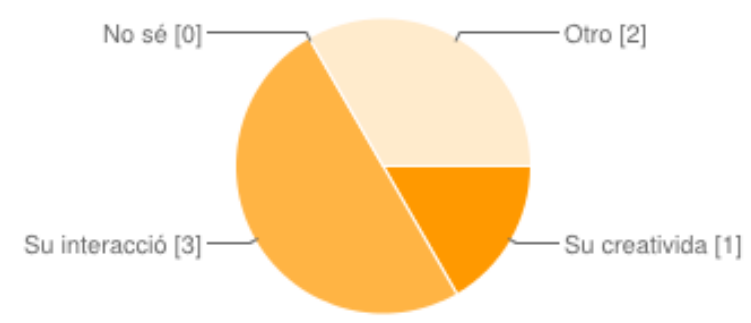

$\begin{array}{lll}\text { Its creativity and originality } & 1 & 17 \% \\ \text { Its active and competitive interaction } & 21 & 50 \% \\ \text { I do not know } & 0 & 0 \% \\ \text { Another answer } & 2 \text { motivation } & 33 \%\end{array}$

Was the teaching unit appropriate for your level?

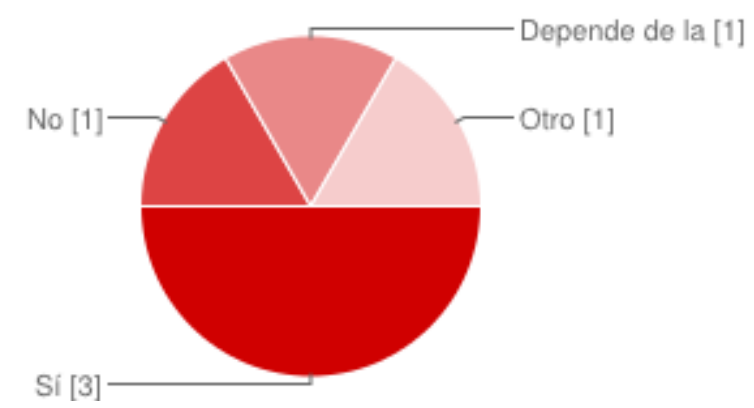

$\begin{array}{lll}\text { Yes } & 21 & 50 \% \\ \text { Non } & 1 & 17 \% \\ \text { It depends on students' needs } & 1 & 17 \% \\ \text { Another answer } & 1 \mathrm{~N} / \mathrm{C} & 17 \%\end{array}$

Was it an inter

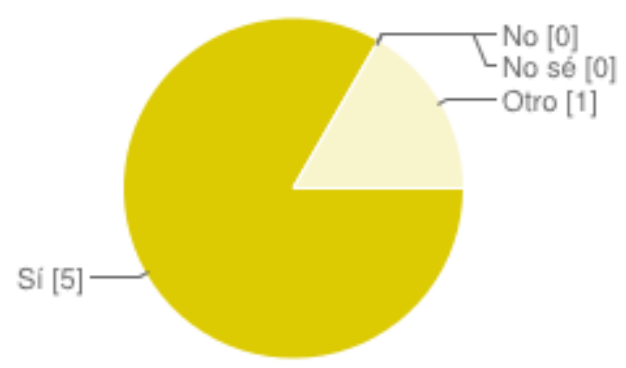


6 | Jurnal Pendidikan Profesi Guru Indonesia, Vol. 1, No. 1, pp. 1-10, February 2021

$\begin{array}{ccc}\text { Yes } & 23 & 83 \% \\ \text { Non } & 0 & 0 \% \\ \text { I do not know } & 0 & 0 \% \\ \text { Another answer } & 1 \mathrm{~N} / \mathrm{C} & 17 \%\end{array}$

Was the input information sufficient for getting through the exercises proposed by the teacher?

Yes

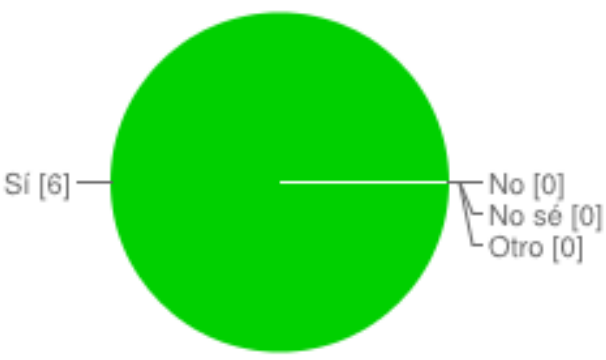

Non

$0 \quad 0 \%$

I do not know

$0 \quad 0 \%$

Another answer

$0 \quad 0 \%$

Were the tasks appropriate for the objectives originally proposed?

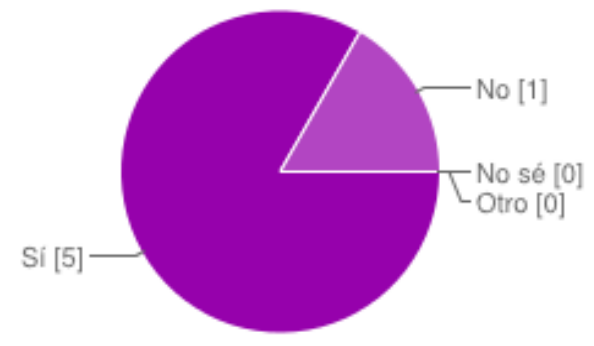

$\begin{array}{ccc}\text { Yes } & 23 & 83 \% \\ \text { Non } & 1 & 17 \% \\ \text { I do not know } & 0 & 0 \% \\ \text { Another answer } & 0 & 0 \%\end{array}$

Did the designed tasks facilitate communication in groups?

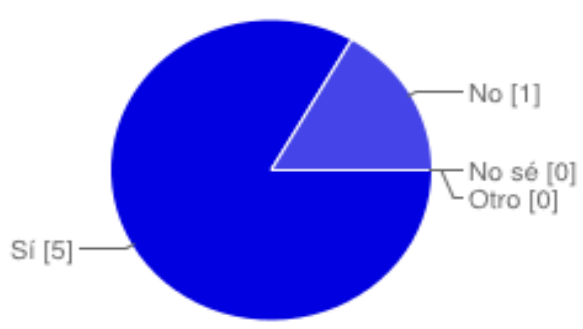




$\begin{array}{lcc}\text { Yes } & 23 & 83 \% \\ \text { Non } & 1 & 17 \% \\ \text { I do not know } & 0 & 0 \% \\ \text { Another answer } & 0 & 0 \%\end{array}$

Was the teaching unit structured in a gradual way (from the simplest to the most difficult tasks)?

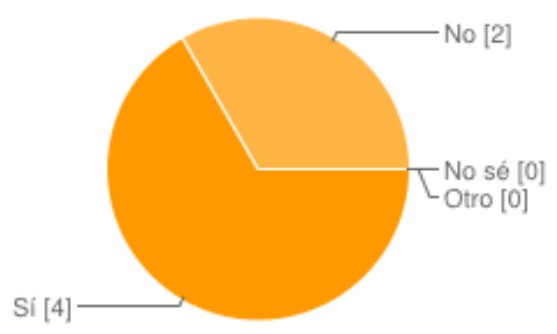

$\begin{array}{lcc}\text { Yes } & 22 & 67 \% \\ \text { Non } & 2 & 33 \% \\ \text { I do not know } & 0 & 0 \% \\ \text { Another answer } & 0 & 0 \%\end{array}$

Were a series of language skills properly integrated into the sequence of tasks? (Reading and listening comprehension skills, written and speaking production skills ...)

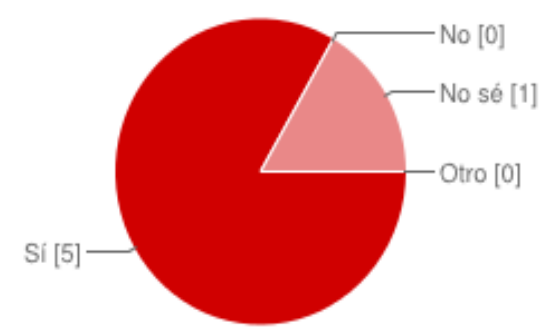

$\begin{array}{lcc}\text { Yes } & 23 & 83 \% \\ \text { Non } & 0 & 0 \% \\ \text { I do not know } & 1 & 17 \% \\ \text { Another answer } & 0 & 0 \%\end{array}$

Were communicative activities correctly integrated with other tasks and exercises designed to give you control over the linguistic system (lexicon and syntax)?

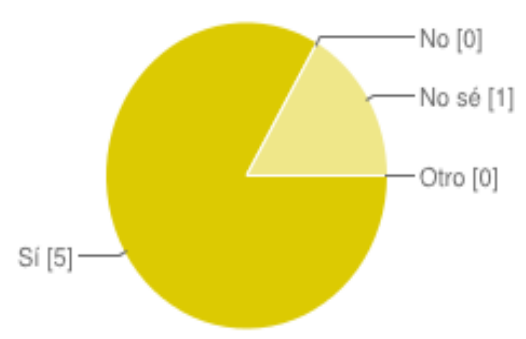




$\begin{array}{lcc}\text { Yes } & 23 & 83 \% \\ \text { Non } & 0 & 0 \% \\ \text { I do not know } & 1 & 17 \% \\ \text { Another answer } & 0 & 0 \%\end{array}$

The data collected allow us to state clearly that all the students found it correct to be how the teaching unit worked; especially, they assessed the active and competitive interaction, which motivates them and makes them direct participants in the learning process. At first, despite the linguistic complexity and a lack of literary knowledge about Gongora, they consider that the teaching unit was appropriate for their level and underline that they found it to be interesting and motivating; it is unanimously highlighted that the input information was sufficient to make it possible for the teaching unit development.

They also mention that the activities were appropriate for the proposed objectives and point a positive outlook out to us about the gradual structuring tasks (from the simplest to the most difficult ones). Likewise, they indicated that a series of language skills were properly integrated into the sequence of tasks (reading and listening comprehension, as well as written and speaking production skills). In the same way, they highlighted the importance of integration of communicative activities with other tasks and exercises designed to provide them with control over the linguistic system (lexicon and syntax), which appear repeated several times in different contexts.

\section{CONCLUSION}

We have shown throughout this paper how we can generate the language, how a literary text may be organized and analyzed according to the discourse analysis perspective. To this end, we must select its significant lexical structures, rhetorical and pragmatic tropes, as well as its syntactic structure to achieve a new Literary Competence, underpinned by extensive research as regards the Task-Based Learning approach, which may also allow us to know the relevance of such literary texts.

\section{ACKNOWLEDGMENT}

We must especially acknowledge this group of students participating whose their native languages were Russian, Chinese, and English, from Polytechnic University of Valencia, Spain.

\section{REFERENCES}

Acquaroni Muñoz, R. (2010). Maneras de ver el bosque: La poesía en el aula de ELE o la construcción de un imaginario compartido. Available at: http://www.anpenorge.no/varios/ actasprovisionalestromso/Viejas/RedEle_ACQUARONI_DEF.pdf. [Accessed April 14, 2018].

Acquaroni, Muñoz, R. (2011). Metáfora y poesía como instrumentos para la comunicación intercultural en el aula de ELE: La conceptualización de la tristeza y de la alegría a través de un poema de Miguel Hernández. Jornadas pedagógicas. Available at: https://www.mecd.gob.es/dam/jcr:6740efe2-859549c2-b773-4500a66b42eb/2012-esp-13-00rosanaacquaroni-pdf.pdf. [Accessed April 12, 2018].

Alonso, D. (1927). Soledades de Góngora. Revista de Occidente. 
Alonso, F., López, G., Manrique, D., \& Viñes, J. M. (2005). An instructional model for web-based elearning education with a blended learning process approach. British Journal of educational technology, 36(2), 217-235. Available at: https://pdfs. semanticscholar.org/500c/ 16c54686ae29f2b997458459de59b51a32d2. pdf. [Accessed April 28, 2018].

Amorós, A. (1998). (Prólogo) Antología poética de Federico García Lorca. Barcelona, ed. Plaza \& Janés.

Andreu-Andrés, M.A; \& Labrador-Piquer, M.J. (2010). “Técnica del puzle de Aronson implementada con recursos electrónicos." Files of the ninth International Conference of the European Association of languages for Specific Purposes. Hamburg. Germany.

Arrieta, J.Á.A. (2001). Góngora y Quevedo a la luz de la metáfora y del símbolo. Available at: http://cvc.cervantes.es/literatura/aiso/pdf/05/aiso_5_017.pdf. [Accessed 14, April].

Bierwisch, M. (1970): "Poetics and linguistics," in Linguistics and literary style, Freedman, D. C. (ed.), Nueva York: Rinehart \&Winston. 97-115.

Bruff, D. O., Fisher, D. H., McEwen, K. E., \& Smith, B. E. (2013). Wrapping a MOOC:

Student perceptions of an experiment in blended learning. Journal of Online Learning and Teaching, 9(2), 187. Available at: http://jolt.merlot.org/vol9no2/bruff_0613.htm. [Accessed April 28, 2018].

Byram, M. (1995). Acquiring intercultural competence. A review of learning theories. Intercultural competence, 1, 53-70.

Caballero Bonald, J.M. (2005). Soledades y otros poemas. EL PAÍS, clásicos populares, 2005. Available at: http://elpais.com/diario/2005/03/06/cultura/1110063604_850215.html. [Accessed April 14, 2018].

Carrió Pastor, M. L. (2009). Enhancing Learner-Teacher Collaboration through the Use of Online Activities. In Teaching academic and professional English online (pp. 107-126). Peter Lang. Available at: https://dialnet.unirioja.es/servlet/articulo?codigo=3330255 [Accessed April 27, 2018].

Celce-Murcia, M., Dörnyei, Z., \& Thurrell, S. (1995). Communicative competence: A pedagogically motivated model with content specifications. Issues in Applied linguistics, 6(2), 5-35. Available at: https://s3.amazonaws.com/academia.edu.documents/34476940/1995_celcemurcia_dornyei_thurrell_ial1.pdf?AWSAccessKeyId=AKIAIWOWYYGZ2Y53UL3A\&Expires=1523672556\&Signature=4yg Ne7S07KnafACwlwi0Ia6AKVY\%3D\&response-content-

disposition=inline\%3B\%20filename\%3DCommunicative_Competence_A_Pedagogically.pdf. [Accessed April 14, 2018].

Colomer, T. (1996). La educación lingüística y literaria en la enseñanza secundaria (Vol. 1). HORSORI EDITORIAL, SL.

Common European Framework of Reference for Languages: Learning, Teaching, Assessment (2001). Council of Europe, Cambridge University Press. Available at: https://www.coe.int/t/dg4/linguistic/source/framework_en.pdf. [Accessed April 11 2018].

De Góngora, L. (2014). Soledades. J. Beverley (Ed.). Eds. Cátedra.

Estaire, S. (2011). Principios básicos y aplicación del aprendizaje mediante tareas. MarcoELE: Revista de didáctica, (12), 5. Available at: https://marcoele.com/descargas/12/estaire-tareas.pdf. [Accessed April 14, 2018].

Gimeno Sanz, A. (2009). Online courseware design and delivery: The InGenio authoring system. Teaching academic and professional English online, 83. Available at:https://www.researchgate.net/profile/Ana_Gimeno2/publication/265467323_Online_Courseware_ Design_and_Delivery_The_InGenio_Authoring_System/links/58406fd208ae8e63e61f8103/OnlineCourseware-Design-and-Delivery-The-InGenio-Authoring-System.pdf [Accessed April 27, 2018].

González Nieto, L. (2001). Teoría lingüística y enseñanza de la lengua. (Lingüística para profesores). Madrid, ed. Cátedra (Grupo Anaya, S.A).

González Rovira, J. (2005). (Introducción): Soledades y otros poemas de Luis de Góngora. Diario El País clásicos populares, Madrid, ed. Santillana.

Hart, C., \& Lukeš, D. (Eds.). (2009). Cognitive linguistics in critical discourse analysis: Application and theory. Cambridge Scholars Publishing.

Hoang, H. (2014). Metaphor and second language learning: the state of the field. The Electronic Journal for English as a Second Language, TESL-EJ, 18(2), n2. Available at:http://www.teslej.org/wordpress/issues/volume18/ej70/ej70a5/ https:/files.eric.ed.gov/fulltext/EJ1045138.pdf [Accessed April 14, 2018].

Jammes, R. (2002). Soledades. Ed. Castalia, Madrid. 
Labrador-Piquer, M. J., \& Andreu-Andrés, M. Á. (2014). Investigación-acción para conseguir grupos colaborativos eficaces. Educatio siglo XXI,32(3 Noviembr), 75-98. Available at:http://revistas.um.es/educatio/article/view/210991 [Accessed April 27, 2018].

Littlemore, J., \& Low, G. (2006). Metaphoric competence, second language learning, and communicative language ability. Applied linguistics, Volume 27, Issue 2, 1 June 2006, Pages 268294, https://doi.org/10.1093/applin/aml004. Available at: http://eprints.bham.ac.uk/70/1/Littlemore __Metaphoric_competence-_L.pdf. [Accessed April 12, 2018].

Luján Atienza, Á.L. (2003). ¿Es un soneto de Góngora también una alabanza? Revista de literatura, 65(129), 31-58. Available at: http://www.upf.edu/todogongora/ _pdf/Lujan__Es_un_soneto _de_ Gongora_tambien_una_alabanza.pdf. [Accessed April 14, 2018].

Maley, A; \& Duff, A. (1990). Literature. Oxford: Oxford University Press.

McDonough, J., \& Shaw, C. (1993). Materials and methods in English Language Teaching (a teacher's guide). Cambridge University Press.

Mendoza Fillola, A. (2008). La educación literaria: bases para la formación de la competencia lectoliteraria. Alicante: Biblioteca Virtual Miguel de Cervantes. Available at: http://www.cervantesvirtual.com/obra-visor/la-educacin-literaria---bases-para-la-formacin-de-lacompetencia-lectoliteraria-0/html/01e1d59a-82b2-11df-acc7-002185ce6064_2.html. [Accessed 14 April, 2018].

Mendoza Fillola, A. (2010). Función de la literatura infantil y juvenil en la formación de la competencia literaria. Available at:http://www.biblioteca.org.ar/libros/154715.pdf. [Accessed April 14, 2018].

Naranjo Pita, M. (1999). La poesía como instrumento didáctico en el aula de español como lengua extranjera. Madrid: Edinumen.

Nederveld, A., \& Berge, Z. L. (2015). Flipped learning in the workplace. Journal of Workplace Learning, 27(2), 162-172.

Available at:https://www.researchgate.net/profile/Zane_Berge/publication/273486956_Flipped_learning_in_th e_workplace/links/55acfcb908ae815a042b4495/Flipped-learning-in-the-workplace.pdf. [Accessed April 28, 2018].

Nunan, D. (1989). Designing tasks for the communicative classroom. Cambridge University Press.

Pellicer de Salas y Tovar, J. (1630). Lecciones solemnes a las obras de Don luis de Góngora, Madrid, Imprenta del Reino, 1630. Edición facsímil a cuidado de Guido Mancini, de la Universidad de Pisa, Hildesheim y Nueva York, Georg Olms Verlag, 1971. Available at: Biblioteca Virtual Miguel de Cervantes (http://www.cervantesvirtual.com/obra-visor/lecciones-solemnes-a-las-obras-de-don-luisde-gongora-y-argote--0/html/). [Accessed April 17, 2018].

Posada, R. (1981). "Jerigóngora" y transformaciones. In Anales de literatura hispanoamericana (No. 10, pp. 213-228). Servicio de Publicaciones. Available at: https://revistas.ucm.es/index.php/ALHI/ article/viewFile/ALHI8181110213A/24466. [Accessed April 14, 2018].

Sanz Pastor, M. (2006). Didáctica de la literatura: el contexto en el texto y el texto en el contexto. Carabela, Madrid, C, 59, 5-23. Available at: https://cvc.cervantes.es/Ensenanza/ biblioteca_ele/publicaciones_centros/PDF/munich_2004-2005/02_sanz.pdf. [Accessed April 13, 2018].

Stubbs, M. (1987). Análisis del discurso, Análisis sociolingüístico del lenguaje natural, Madrid, Alianza. 